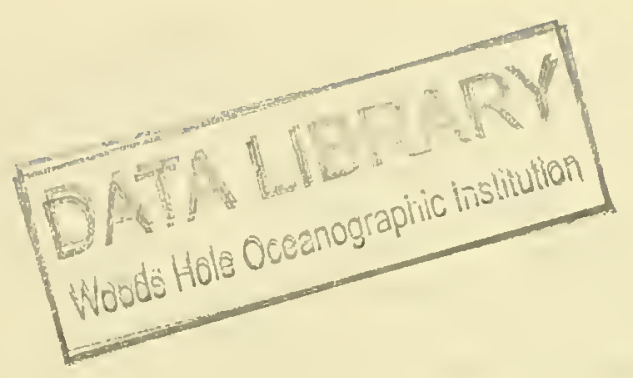

$$
\begin{aligned}
& \text { REPORT } \\
& \text { of the }
\end{aligned}
$$

UNITED STATES PARTICIPATION

In the

INTERNATIONAL INDIAN OCEAN EXPEDITION

John Lyman

Indian Ocean Coordinator

National Science Foundation

July 20, 1962

GC
63
. \pm 5
L9
1962 


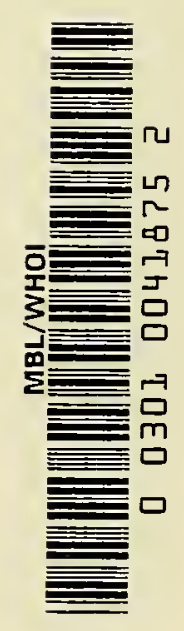




\section{ORGANIZATION AND HISTORY}

The International Indian Ocean Expedition (IIOE) was conceived at the first meeting of the Special Committee of Oceanic Research (SCOR) of the International Council of Scientific Unions (ICSU) in September 1958. United States participation was initially planned by the Committee on Oceanography of the National Academy of Sciences (NASCO). The preliminary plan was presented to the Federal Council of Science and Technology in May 1960, and approval for United States participation was announced by the White House on June 13, 1960. Scientific responsibility for the United States participation was assigned to the National Academy of Sciences - National Research Council, and the National Science Foundation was directed to plan and coordinate Federal support for United States participation in the program.

At the request of the Director of the National Science Foundation, other Federal agencies with potential interest in the IIOE appointed representatives to serwe as single points of contact and facilitate communication among the agencies. As a result of meetings of these representatives held during the summer of 1960 , it was determined that the preliminary plans were inadequate to carry out the steted aims of the IIOE, particularly in the areas of biological oceanography and of air-sea interaction, and following international meetings held by SCOR at Copenhagen and Helsinki in July 1960, NASCO enlarged its Indian Ocean Expedition Panel, set up five Working Groups (Biology; Geology, Geophysics, and Bathymetry; Meteorclogy; Physical and Chomical Oceanography; and Expedition Data, respectively), and drew up an enlarged program for $U . S$. participation.

During the spring of 1962 it was agreed between SCOR and the new International Oceanographic Commission (IOC) that henceforth the Secretary of the IOC would have responsibility for coordination of the IIOE. Simultaneously NASCO, as the United States adhering body to SCOR, has felt it inappropriate for it to continue to coordinate the United States participation in the IIOE, and full responsibility for the United States program thus has been assumed by the National Science Foundaticn.

\section{FINANCIAL SUPPORT}

The original Presidential directive in June, 1960, provided that United States participation in the IIOE would be funded by normal budgetary process. Accordingly, the United States Navy, historically the chief Federal sponsor of basic research in oceanography through its Office of Naval Research, agreed to permit vessels whose operations it finances through research contracts at Scripps Institution of Oceanography, Woods Hole Oceanographic Institution, and Lamont Geological Observatory to undertake cruises to the Indian Ocean. Iikewise the datamprocessing facilities at the Navy Oceanographic Office were put at the disposal of the U. S. participants, and survey vessels in the Indian Deean were assigned to make oceanographic observations in support of the IIOE. 

The National Science Foundation, which supports research through grants made as the result of applications proposing specific research projects, encouraged United States research institutions to submit proposals for research connected with the IIOE, and took steps to augment its available research funds by the inclusion of a special item for the IIOE, commencing with its Fiscal Year 1962 budget.

Other Federal agencies have been less successful in obtaining the additional funding required to permit them to operate themselves in the Indian Ocean or to support research there in fields related to their specific missions, and in some cases the National Science Foundation has transferred funds to enable these agencies to carry out urgent programs related to the IIOE.

The following tabulation, extracted from the 1963 National Oceanographic Program, prepared by the Interagency Committee on Oceanography of the Federal Council of Science and Technology, (with the addition of information from the U.S. Weather Bureau) summarizes planned Federal support of the U.S. participation in the IIOE through Fiscal Year 1963:

\section{THOUSANDS OF DOLLARS}

$\begin{array}{lcrr}\text { Fiscal Year } & \underline{1961} & \underline{1962} & 1963 \\ \text { USN } & 760 & 580 & 1,300 \\ \text { NSF } & - & 1,500 & 4,000 \\ \text { Bur.Com。Fish. } & - & - & 70 \\ \text { Weather Bureau } & - & - & 792\end{array}$

SCIENTIFIC PROGRAM BY DISCIPLINES

The United States program for the IIOE, in accordance with the original stated aims of the expedition, is devoted to the scientific examination of four great areas of interest in the Indian Ocean. The first of these concerns itself with the problems of why there is an ocean basin in the first place; what are the forces that have shaped and are continuing to shape the basin; what are the resemblances between this piece of the earth's crust and any other; and how is the basin of the Indian Ocean dissimilar from other ocean basins? The techniques used in attempting to answer these questions are primarily geophysical and geological, and they have been or will be employed on expeditions sent out by Scripps Institution of Oceanography, Lamont Geological Observatory, Stanford University, and Woods Hole Oceanographic Institution.

The second broad erea of investigation involves the chemical and physical description of the waters of the Indian Ocean, and the study of their motions. The techniques used involve sampling of the waters in predetermined patterns, with respect both to horizontal distribution and to vertical spacing of the samples; concurrent precise measurements of water temperature; subsequent chemical and isotopic analyses of the water samples; and determination of current flow at 

Various depths by all possible means. All United States ships participam ting in the IIOE will be equipped for such water sampling, and the direct measurement of current flow is the particular object of a University of Rhode Island expedition embarked in the Scripps Institution vessel ARGO.

The third major field of interest is the living populations, plant and animal, of the Indian Ocean. All United States ships will be equipped to sample plankton and to observe surface biological phenomena, and some will measure primary productivity. The research vessel ANTON BRoth will have biological oceanography as her primary mission, and the Staniord University vessel TE VEGA will concentrate on biological and physiological studies of island groups and other shallow water areas.

The fourth main area of research is concerned with the interaction between the ocean and the atmosphere. Several of the U. S. research vessels that will work in the Indian Ocean will be equipped to make uppermair meteorological observations, but the United States will have the greater part of its meteorological effort based ashore. Observations from meteorological aircraft of the U. S. Weather Bureau and of Woods Hole Oceanographic Institution, working in connection with the International Meteorological Center that has been established with the assistance of the Government of India and the United Nations Special Fund; from meteorological satellites; and from meteorological buoys (to be planted in the Bay of Bengal and Arabian Sea. with the help of the Indian Navy), will be utilized in the program.

SCIENTIFIC PROGRAMS OF INSTITUTIONS

As indicated in the preceding paragraphs, research programs of all United States vessels participating in the IIOE will contribute to at least two of the four fundamental areas of interest; many will contribute to three: and some to all four. For this reason, it is more practical to describe the programs in dotall by setting forth the past, present, and planned cruises of each institution.

\section{SCRIPPS INSTITUTION OF OCEANOGRAPHY}

The Seripps Institution of Oceanography of the University of California at San Diego plans to undertake three major cruises to the Indian Ocean under the overall direction of Dr. Robert L. Fisher. The first of these, called MONSOON, was carried out by the research vessel ARGO according to the following itinerary: 

1960

19 October

23 October

13 November

14 November

18 November

7 December

10 December

\section{7}

2 January

6 January

15 January

17 January

22 January
Schedule

ARGO left Darwin

Joined by $M / N$ MALITA

MALITA detached

ARGO arrived Jakarta

ARGO left Jakarta

Arrived Mauritius

Left Mauritius

Arrived Fremantle

Same

Left Fremantle

Arrived Hobart

Left Hobart

Arrived Wellington

\section{Program}

Geological-geophysical exploration, under Dr. R. L. Fisher. Emphasis on two-ship seismic refraction work between Darwin and Jakarta.

Same program, except for seismic refraction. Emphasis on heat flow, large-volume water-sampling; topography.

The following observations were made between Darwin and Wellington:

\section{Underway Observations}

Precision depth recordings

Gravimeter recordings

Towed proton precession magnetometer recortings

Insect collection, nets on superstructure

Bathy thermograms

Surface water samples (for radio caesium).
17,000 miles

15,500 miles

16,000 miles

13,800 miles

618

29

Station Operations

Seismic refraction stations

Gravity corres

Piston cores

Heat flow measurements by temperature probe

Hydrographic casts to bottom 

Station Operations (Continued)

Special 2-liter water samples

Midwater trawl hauls

One-meter standard plankton tows

17-cm vertical microplanton hauls

Bottom samples (biological)

Rock dredges

Large-yolume water samples

(c) and trace elements

Bottom photography
13 stations

13

18

49

7

6

18 stations

18 stations

In addition, some seismic reflection shooting was carried out, occasional air samples were taken, gravity was measured in ports of call; rocks and biological specimens were collected in ports of call; and large organisms were diponetted at light lures on most night stations.

The second Scripps cruise, called LUSIAD, is also being carried out by the $\mathrm{R} / \mathrm{T} \mathrm{ARCO}$, according to the following itinerary:

1962

27 June

$24 \mathrm{JuIy}$

$27 \mathrm{July}$

25 August

28 August

25 September

1 October

26 October

28 October

29 Notember

2 December

23 December

27 December
Schedule

Leave Singapore

Arrive Mombasa

Leave Mombasa

Arrive Collombó

Leare Colombo

Arrive Cochin

Leave Gochin

Arrive Port Iouis, Mau.

Leave Port Louts

Arxive Fremantle

Leave Fremantle

Arrive Port Darwin

Leave Port Darwin

\section{Program}

Studies of equatorial circulation during one monsoon season, under Dr. John Knauss. Hydrographic casts and direct current obsezva. tions with the aid of anchored buoys.

In company $R / N$ HORIZON: two-ship

seismic refraction work under Drs. George G. Shor, R.W. Raitt, and R. Lo Fisher. BottomsampIing: hydrographic casts; heat-flow measurements. Cli collections under Dr.N.W。Ra'restraw. Topography, magnetism, gravity, under"way measurements: under Dr. R. I. Fisher。

1963

15 Jenuary

18 January

14 February

17 February

15 May

18 May

7 June
Arrive Jakarta

Leave Jakarta

Arrive Visakhapatnam

Leave Visakhapatnam

Arrive Mombasa

Leave Mombasa

Arrive Cape Town
Repeat equatorial circulation during second monsoon, under Dr. Knauss. Geological-geochemical-geophysical observations wader Drs. George Bien, John Belshé, and Charles Keeling. 
The itinerary of the $\mathrm{R} / \mathrm{V}$ HORIZON during LUSIAD is scheduled as follows:

1962

16 September

17 September

27 September

1 october

26 October

28 October

29 November

2 December

23 December
Schedule

Leave Suez

Arrive Aden

Leave Aden

Arrive Cochin

Leave Cochin

Arr. Port Louls, Mau.

Leave Port Louis

Arrive Fremantle

Leave Fremantle

Arrive Port Darwin
Program

Conduct underway reflection profiling of Red and Arabian Seas.

In company $R / V$ ARGO; two-ship

seismic refraction work under

Drs. George G. Shor, R. W. Raitt, and R. L. Fisher. Bottom-sampling, hydrographic casts, heat-flow measurements.

Besides serving as consort to the R/V ARGO between Cochin and Port Darwin, the HORIZON will carry out hydrographic studies between Suez and Cochin and from Port Darwin she will return to San Diego via the Pacific. Figure 1 shows the tract of MONSOON and Figure 2 that of LUSIAD.

The third planned Scripps cruise will be carrled out by the $R / V$ SPENCER F. BAIRD between February and May 1964 under W. R. Riedel. Emphasis will be on detailed stratigraphic, geochemical, and heat flow development in the central and eastern Indian Ocean where earlier cruises have indicated areas of especial interest. Continuous underway magnetometer recordings will also be made.

LAMONT GEOLOGICAL OBSERVATORY IIOE.

Three cruises of the $R / V$ VEMA have been planned as part of the

VEMA 16 Itinerary Figures 3 and 4

27 December 59

22 January 60

25 January 60

22 February 60

26 February 60

14 March 60

16 March 60

31 March 60
Left Cape Town

Arrive Mauritius

Left Mauritius

Arrive Fremantle

Left Fremantle

Arrive Adelaide

Left Adelaide

Arrive Wellington

Under the direction of C. Fray, as Chief Scientist, VEMA made the passage from Cape Town to Mauritius and from Mauritius to Fremantle. More than 8300 miles of topographic track was recorded with a precision depth recorder in the southern Indian. Ocean. The existence of a 



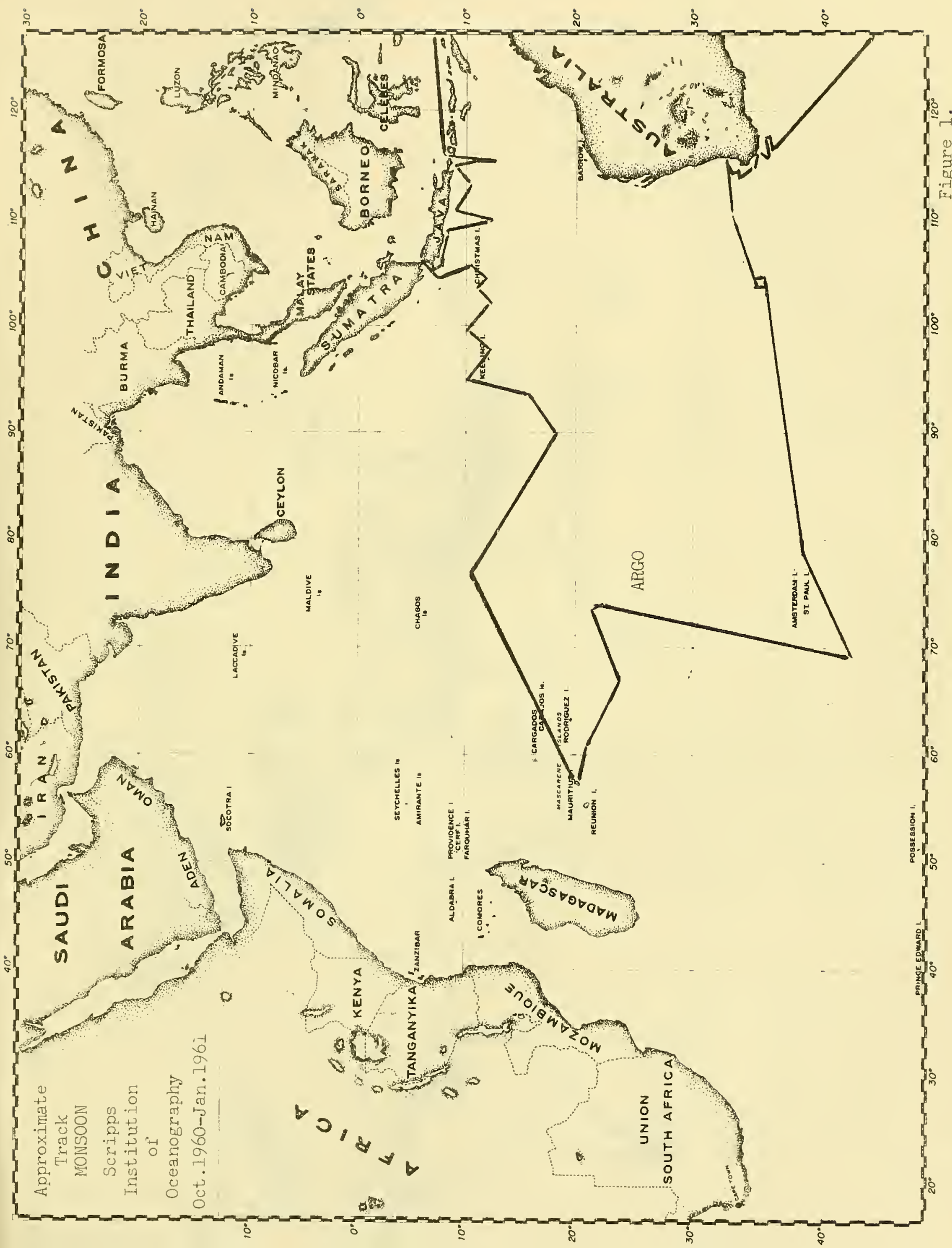



$-8-$

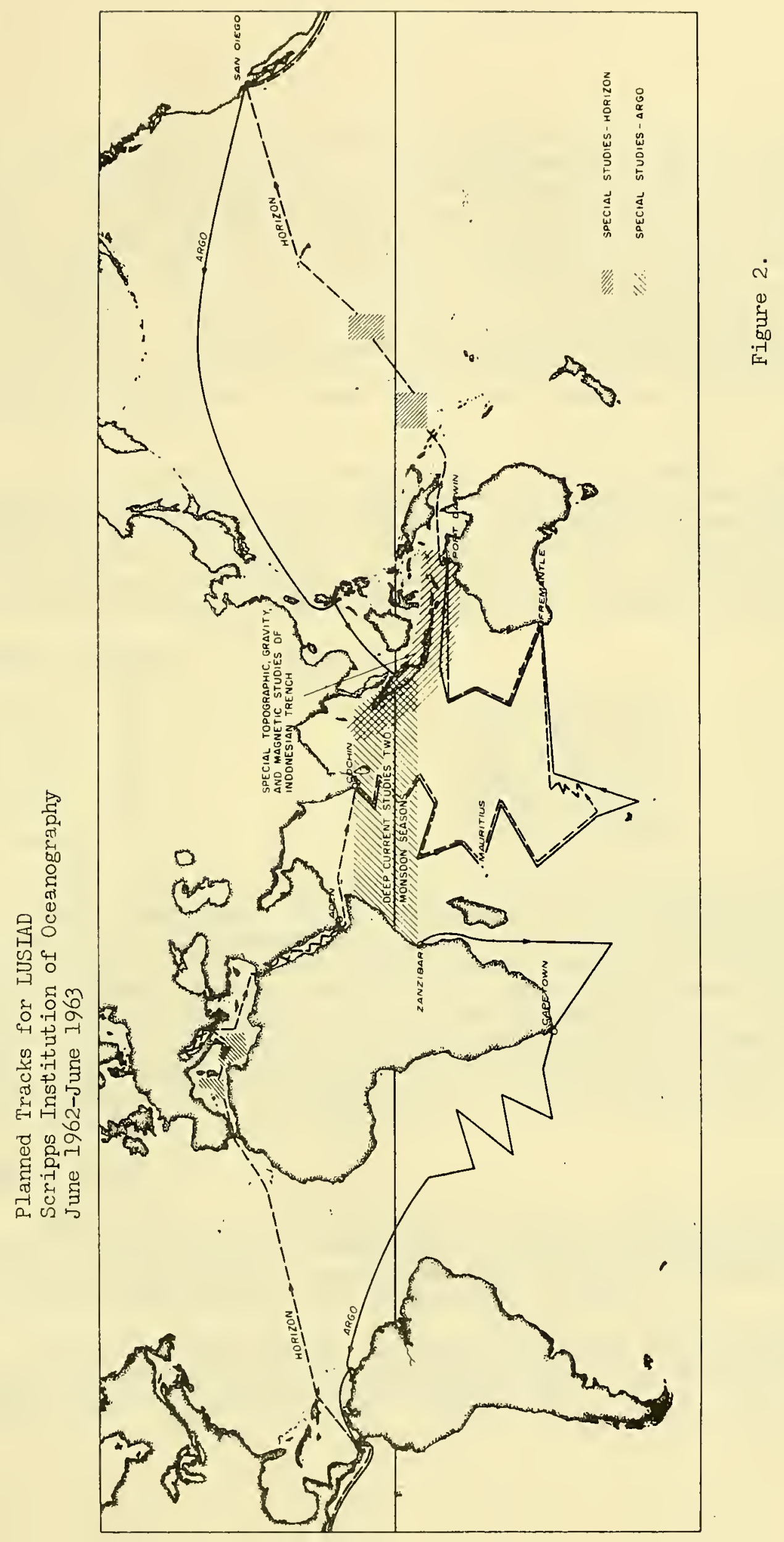



mid-ocean ridge and associated rift valley was verified by six crossings of this topographic feature. A towed magnetometer produced a continuous plot of the total intensity of the earth's magnetic field along the ship's track. Forty-seven piston cores of the bottom sediment were obtained. Multiple photographs of the bottom were taken at 23 stations. Thirty hydrographic stations were occupied and consisted of serial observations of temperature, salinity, and oxygen. Sixteen large volume water samples, representative of all of the water masses, were collected for $\mathrm{C}-14$ age determination. Biological collections included 11 bottom trawls and 80 plankton samples. Additional observations included measurements of the heat flow through the ocean floor, and propagation of sound through the SOFAR channel.

Under the direction of John E. Nafe, as Chief Scientist, VEMA made passages from Fremantle to Adelaide and from Adelaide to Wellington. During the early part of this program seismic refraction measurements were undertaken in cooperation with HMAS DIAMANTINA. During the remainder of the passage the program of observations under way and at stations was closely similar to that of the Cape Town to Fremantle traverse.

VEMA 18 Itinerary $\quad$ Figure 5

3 June 62

20 June 62

22 June 62

12 July 62

$14 \mathrm{JuIy} \quad 62$

1 August 62

\author{
Leave Cape Town \\ Arrive Mauritius \\ Leave Mauritius \\ Arrive Fremantle \\ Leave Fremantle \\ Arrive Wellington
}

Manik Talwani, as Chief Scientist, directed the work of VEMA from Cape Town to Mauritius. Marcus Langseth was in charge from Mauritius to Wellington. The underway program included continuous magnetic, topographic, gravity, and seismic reflection measurements. At the Stations cores and Camera Stations were the most common combinations, with more emphasis than usual being placed on plankton sampling. In the area south of Australia a number of bottom trawl stations have been occupied. The passage Irom Bass to Wellington will begin about July 25th. Particulax emphasis is placed on comparison of total sediment thickness with that found in the Atlantic Ocean.

VEMA 19 (1963)

VEMA 19 (1963) is being planned to enter the Indian Ocean via elther Suez or Cape Town, proceeding to Kerguelen and thence to Fremantle. The new $R / V$ CONRAD, to be operated by Lamont Geological Observatory, will also spead three months in the Indian Ocean in 1963.

During all VEMA cruises, the following program is being carried out under the supervision of the investigators named. Dr. Maurice Ewing is the principal investigator on all VEMA cruises. 



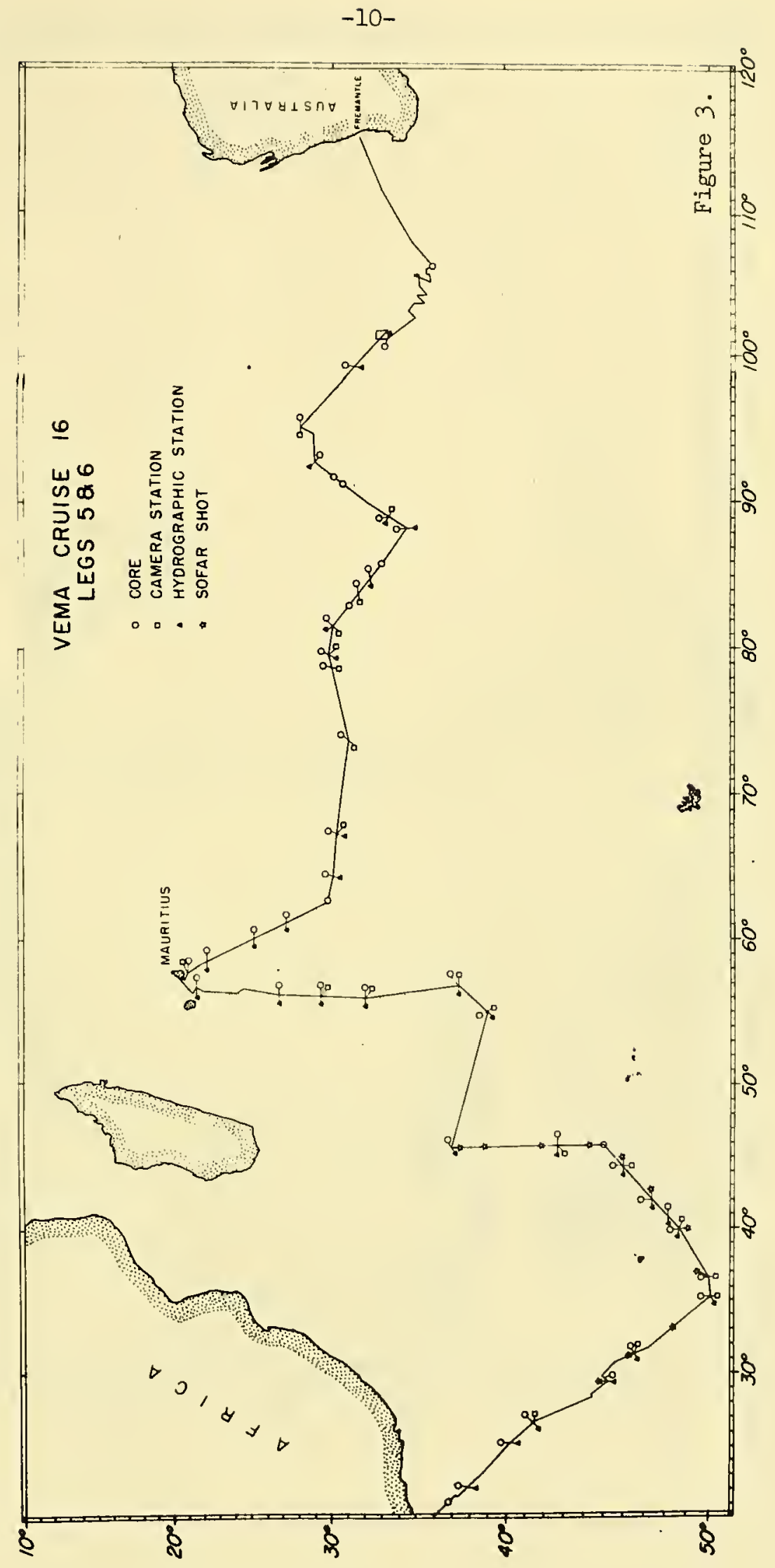





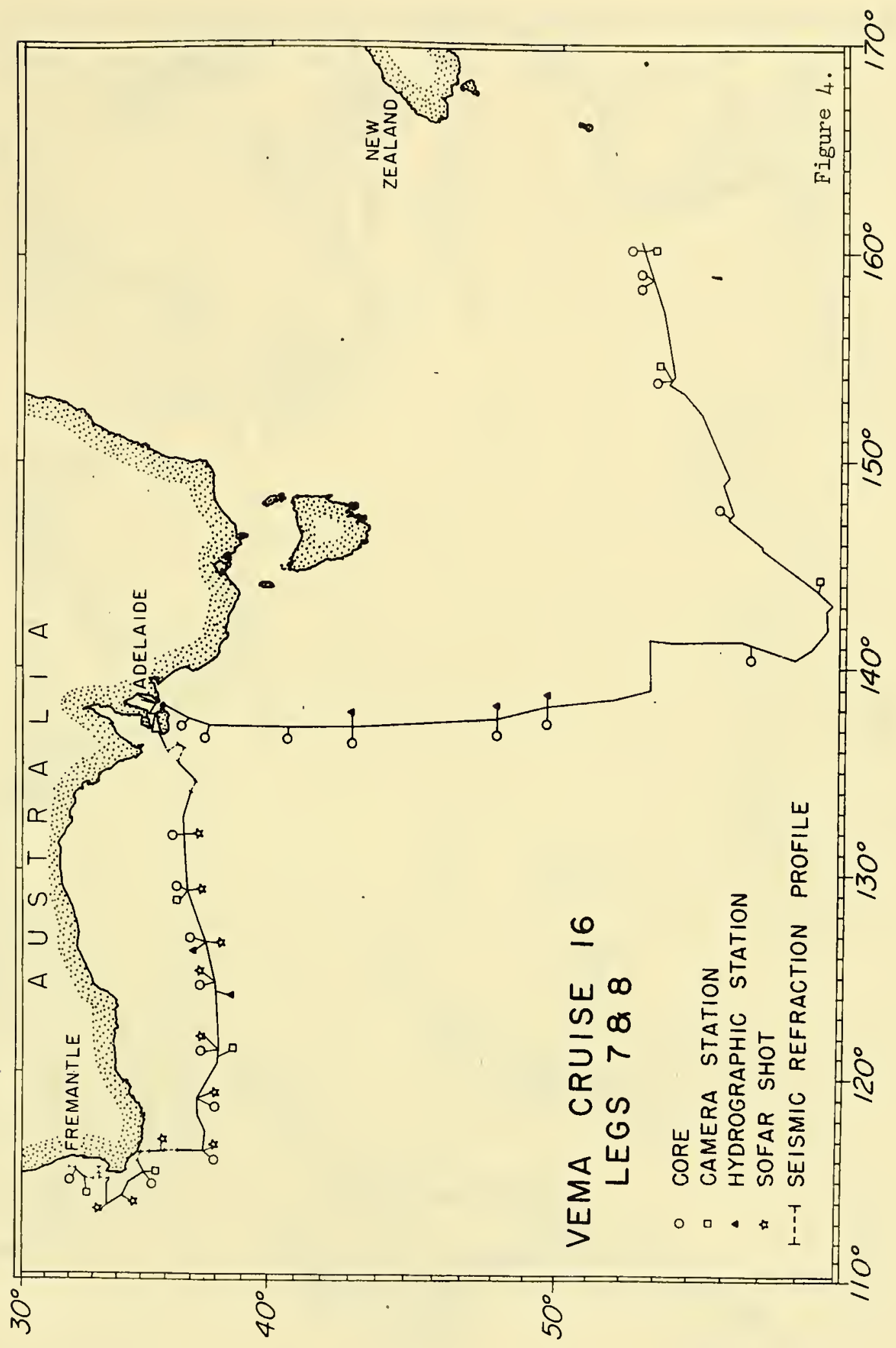





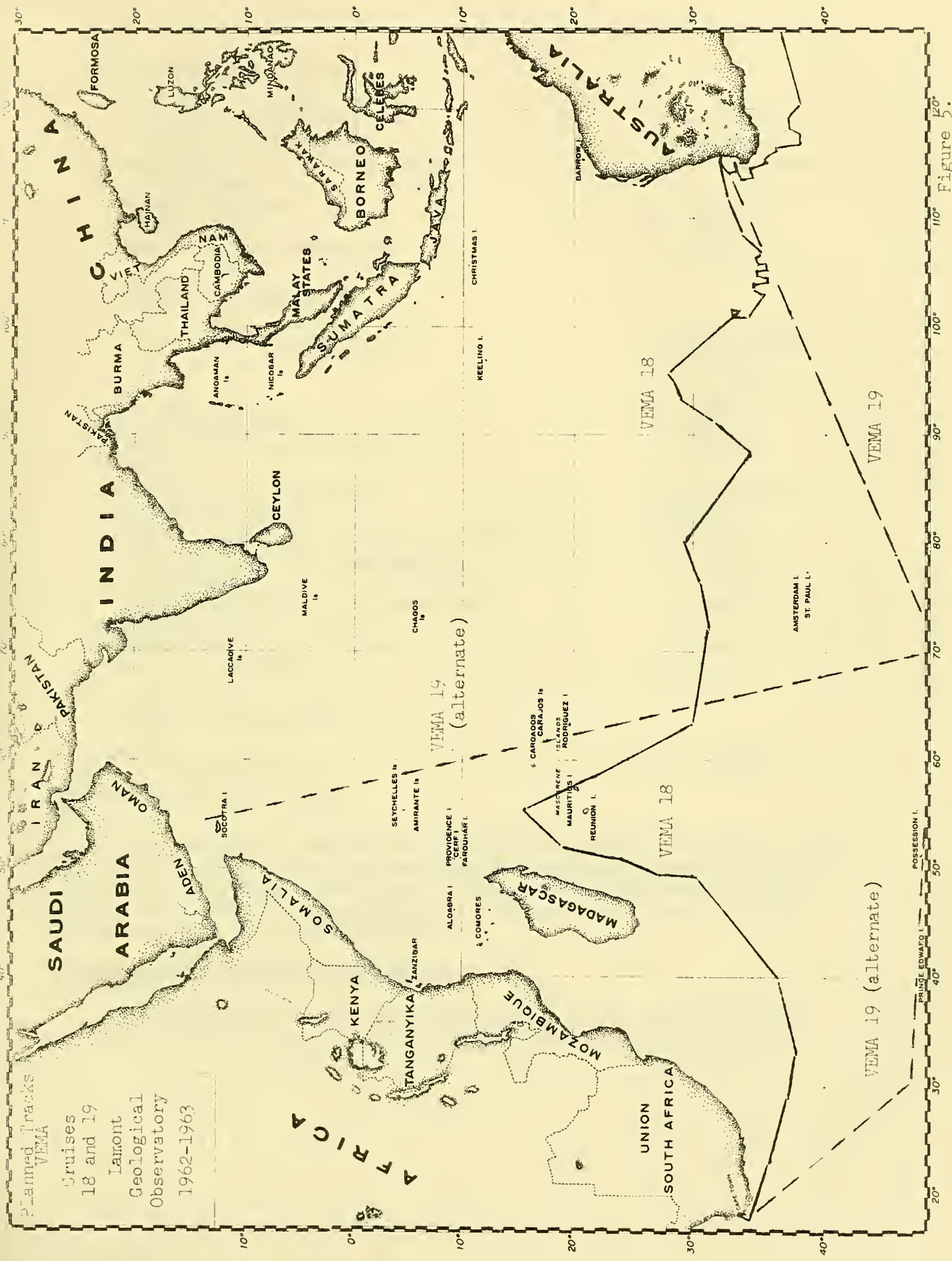



Underway Observations

Precision depth recordings

Bruce Heezen

Gravimeter recordings

J. L. Worzel

Magnetometer total field intensity

J. R. Heirtzler recordings

Bathythermograms

Selsmic reflection

R. Gerard

Surface water temperature

J. I. Ewing

M. Ewing

Station Operations

Seismic refraction profiles

(Charles Drake

(J. E. Nafe

(J. I. Ewing

Gravity cores

Hydrographic casts

Large-volume samples for $\mathrm{C}^{14}, \mathrm{H}^{3}$,

C. Fray

R. Gerard

$\mathrm{Sr}, \mathrm{Cs}$

Microbiological sampling

Plankton sampling

Bottom trawling for biological specimens

W. Broecker

Sound velocity and transmission

Measurements

Bottom temperatures and temperature gradients

Bottom dredging for rocks

P. R. Burkholder

Alan Bé

Alan Bé

J. I. Ewing

M. Langseth

Bottom Photography

C. Fray

M. Ewing

In Port observations

Rock collections

C. L. Drake

UNIVERSITY OF RHODE ISLAND

Under Dr. John A. Knauss, the Narragansett Marine Laboratory of the University of Rhode Island is carrying out two three-month studies of the equatorial current circulation in the Indian Ocean aboard the $R / V$ ARGO, whose cruise itinerary has been given above. Planned locations of the sections are shown in Figure 6 .

WOODS HOLE OCEANOGRAPHIC INSTITUTION

The Woods Hole Oceanographic Institution, under the direction of Dr. Paul Fye, is planning the following cruises to the Indian Ocean. 



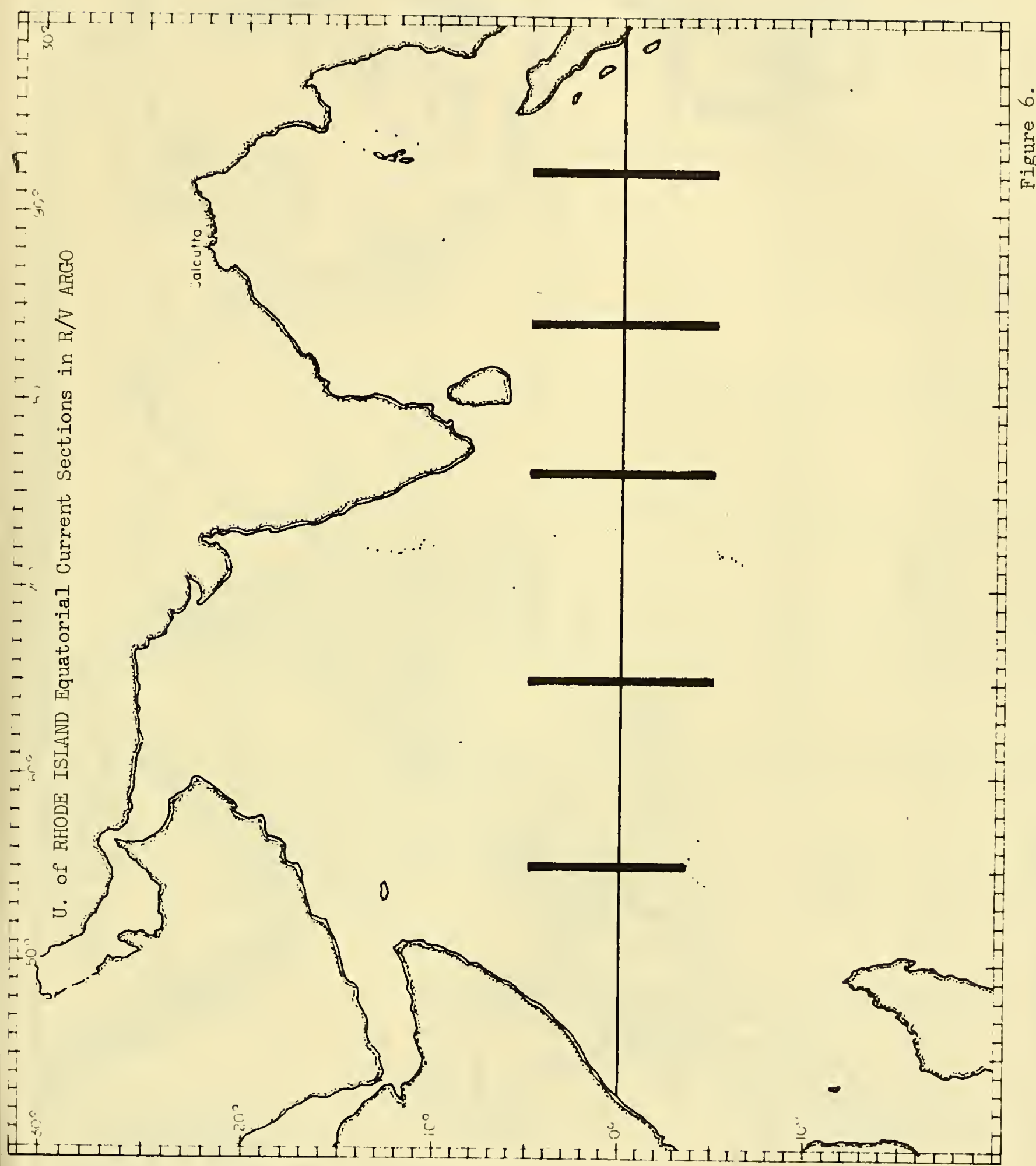










$\underline{1963}$

June - November ATLANTIS II

Physical and chemtcal studies in Red and Arabian Seas and Agulhas Current (Figure 8)

September

1964

CHAIN

Geophysics and submarine geology between Socotra and Cape Agulhas (Figure 7)

March

September

$\underline{1965}$

CHAIN

Geophysics and submarine geology, Cape Agulhas to Laccadives, Chagos to India, India to Suez (Figure 7)

March

February - July ATIANIS II Physical and chemical studies in Red and Arabian Sea and Agulhas Currents (Figure 8)

The programs indicated for the CHAIN and ATLANTIS II respectively are the primary ones. The CHAIN cruises will also include physical and chemical oceanography and the ATLANTIS II cruises geophysics and submarine geology.

Key scientists involved in the above programs are: Earl E. Hays, J. B. Hersey, C. O'D. Iselin : and A. R. Miller.

In addition, the Woods Hole Oceanographic Institution will also have scientific responsibility for the operation of the $R / V$ ANTON BRUUN, which will be devoted primarily to biological work. Under the direction of Dr. John H. Ryther, assisted by Dr. Edward Chin, the following schedule has been established:

$\underline{1963}$

February - April

May - July

August - September
1. Bay of Bengal, Andaman Sea, and Nicobar Islands, A. B. (Figure 9)

2. Bombay-Colombo-Mauritius-Bombay, A, C . (Figure 10)

3. Bombay - $40^{\circ} \mathrm{S}$ - Tamatave; A. C. (Figure 9) 



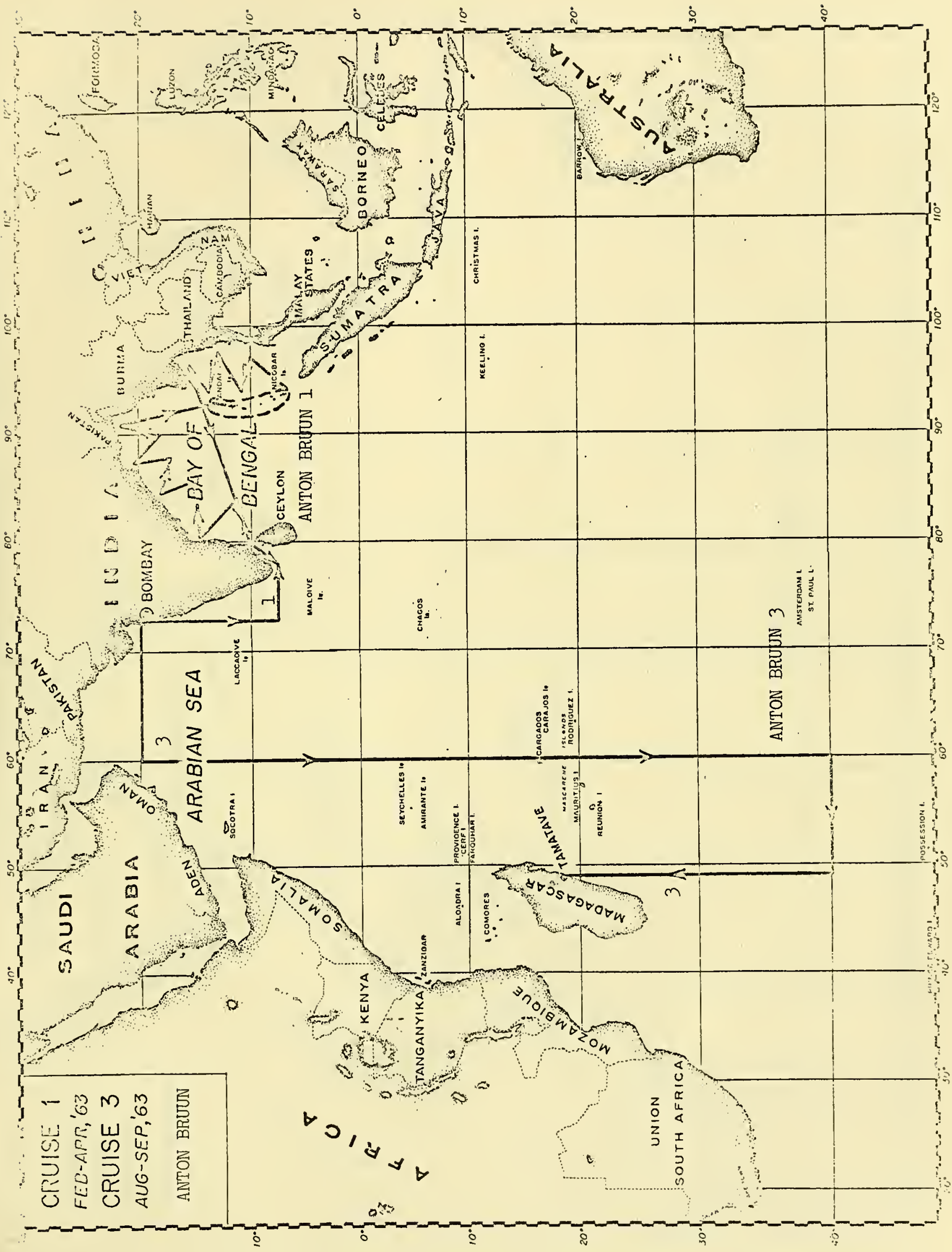





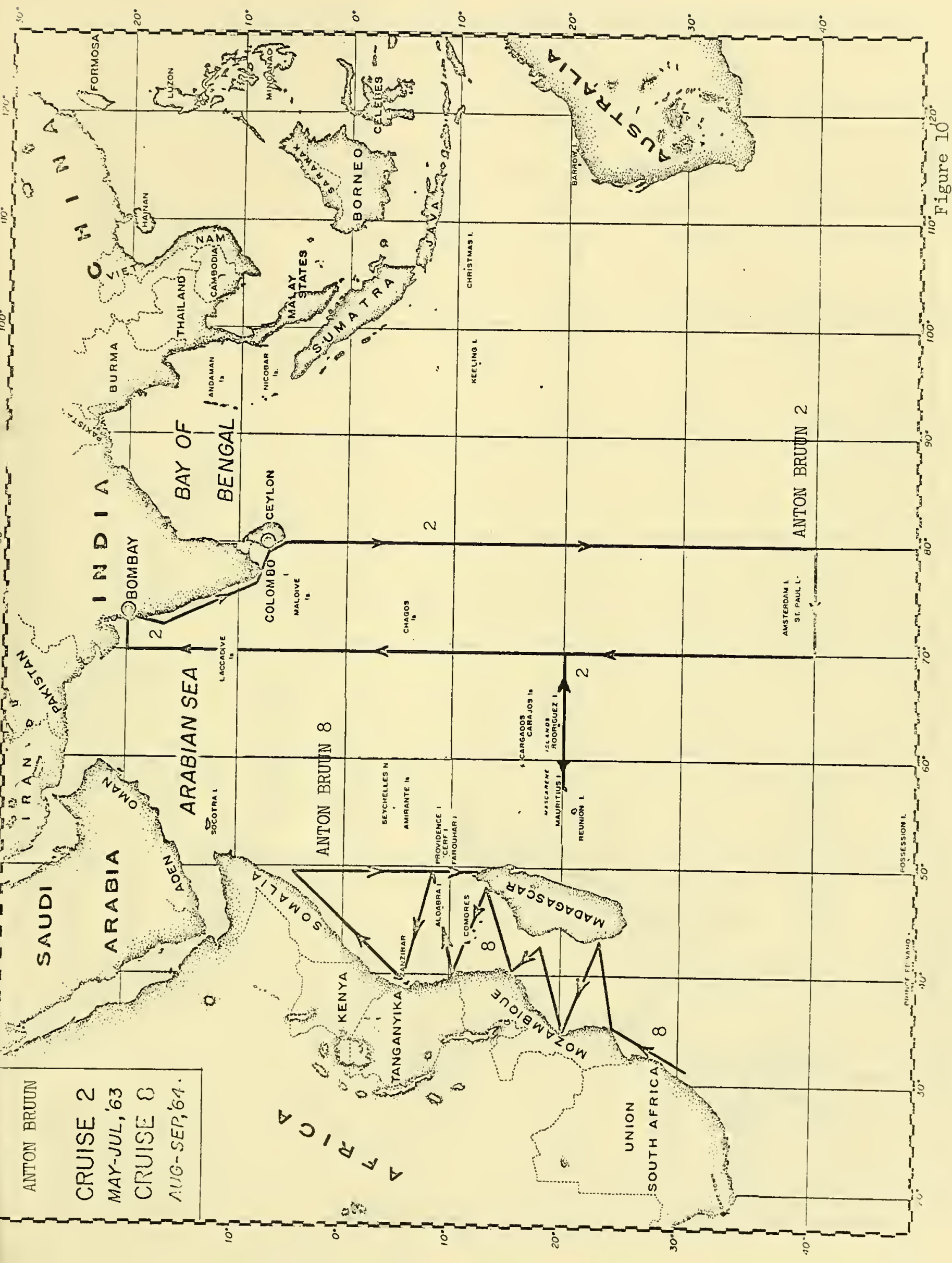





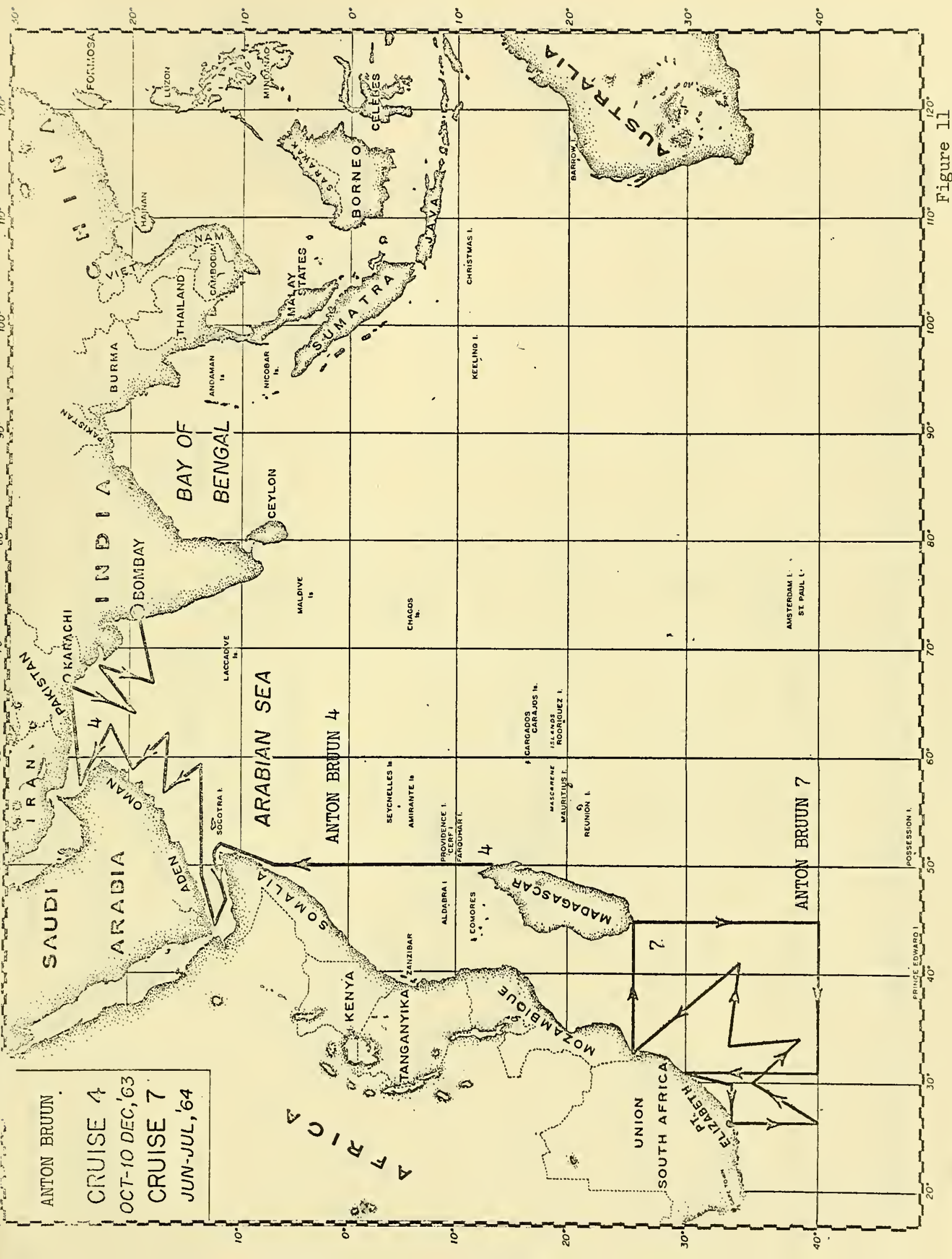





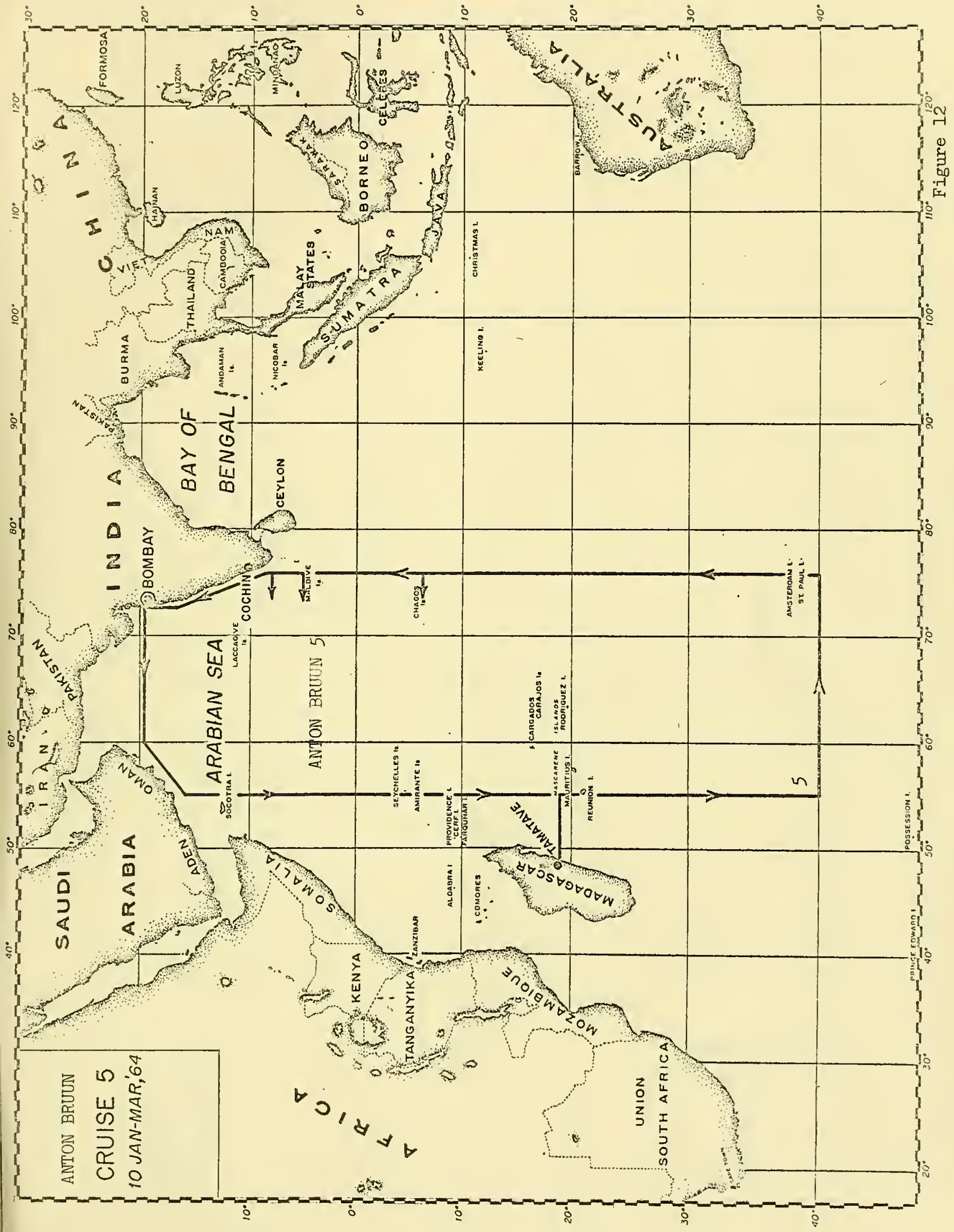





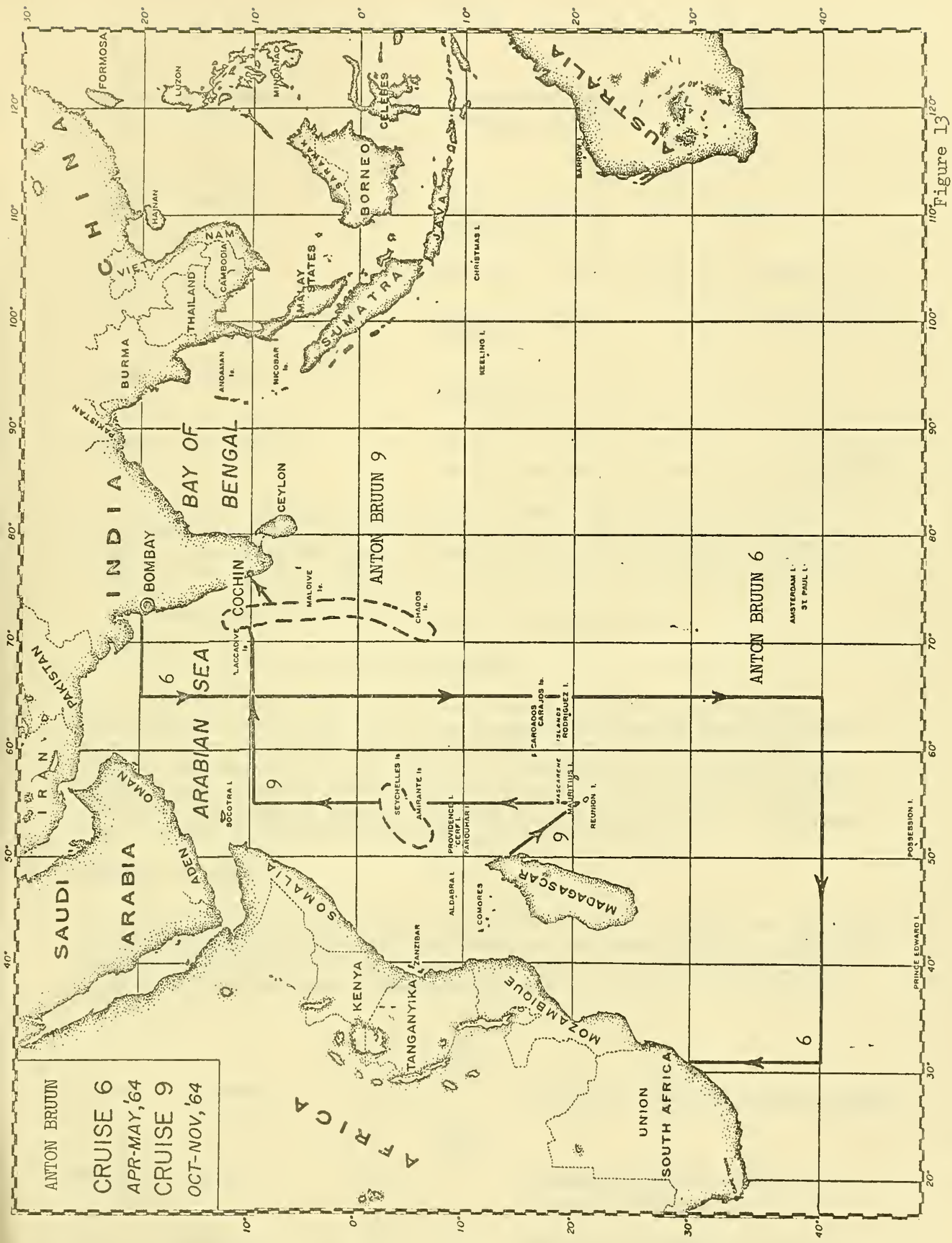



October - December

April - May

June - July

August - September

October - November 9
4. Arabian Sea and Gulf of Aden, A, B. (Figure 11)

1964

5. Bombay-Mauritius - $40^{\circ} \mathrm{S}$ - Bombay, A, C. (Figure 12)

6. Bombay - $40^{\circ} \mathrm{S}$ - Durban, A, C. (Figure 13)

7. Agulhas Current, A, B. Deep water benthos. (Figure 11)

8. Mozambique and Somali Currents, A, B. (Figure 10)

9. Nosy Be - Reunion - Bombay, A, B. diving and collecting from small boats (Figure 13)

A. Complete hydrographic stations to the bottom, light penetration measurement, primary production ( 14 ), phytoplankton pigments, zooplankton sampling from selected depth intervals, mid-water trawl hauls. Station intervals $120 \mathrm{mi}$ on meridional sections, closer on coastal cruises.

B. Dredging and bottom trawling on continental shelf.

C. Midwater and/or surface collecting.

Under the direction of Professor Andrew F. Bunker, Woods Hole Oceanographic Institution will also operate a four-engined meteorological aircraft over the Indian Ocean during 1962, 1963, and 1964. The plane will be instrumented for the lay-scale determination of turbulent transport and the various terms in the heat budget. Four six-week trips are planned. The ATLANTIS II will be equipped with meteorological instruments and will make observations in assistance of the program.

STANFORD UNIVERSITY

The research vessel TE VEGA will undertake three cruises for biological and geological collection and observation in and around island groups and shallow water areas, landing shore parties on atolls for intensive two to three - month studies. The following schedule has been established (F1gure 14):

$\underline{1963}$

October - December

A

Singapore-Nicobars-Andamans-Colombo

1964

February - April

B

Colombo-Laccadives-Maldives, Chagos, Mauritius 



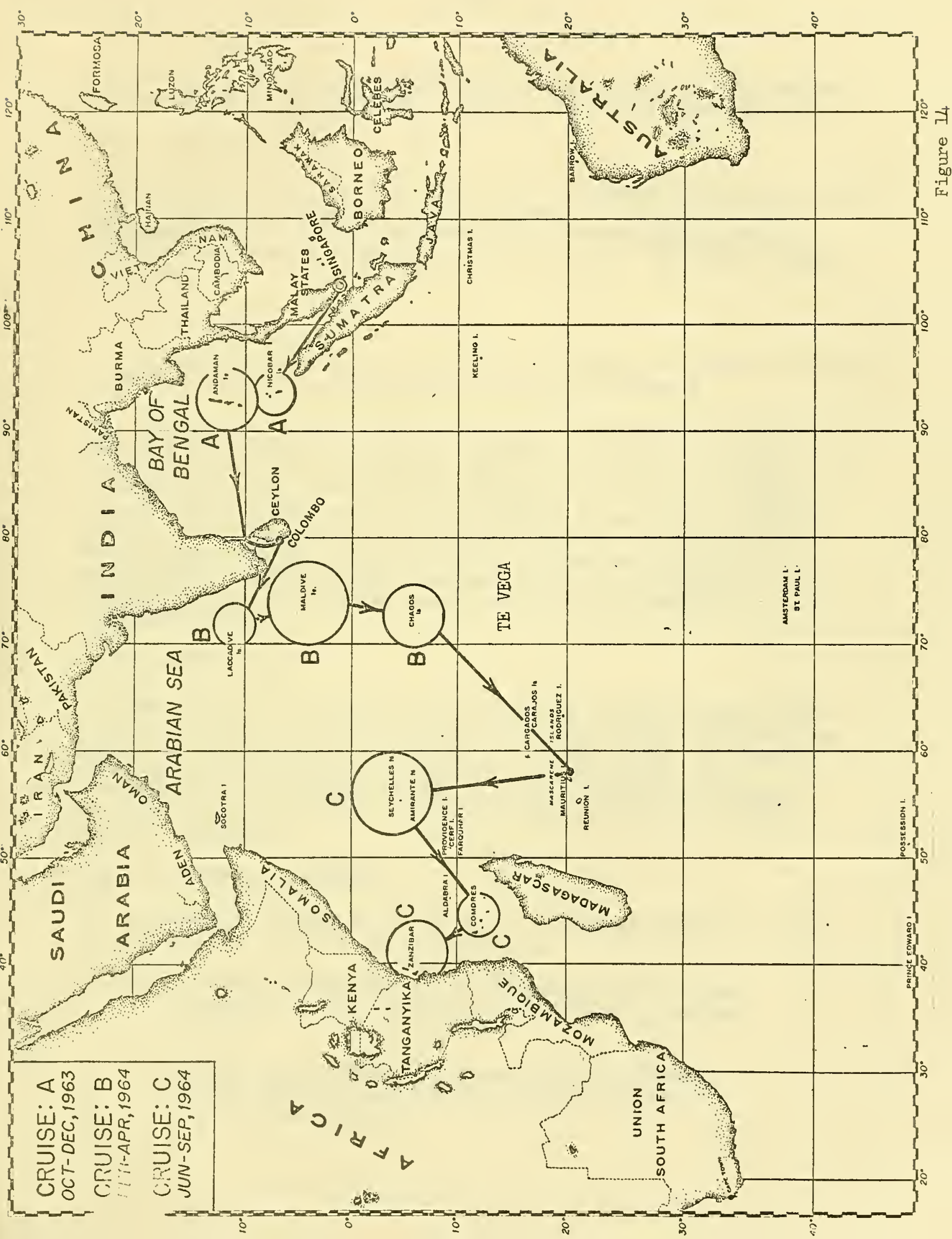



On Cruise C a party of physiologists will be embarked, and emphasis will be placed on obtaining live Latimeria for physiological study.

U. S. COAST GUARD

During May 1961, the U. S. Coast Guara Icebreaker EAST WIND, returning from a trip to the Antarctic with oceanographic observers from the Hydrographic Office aboard, occupied a line of hydrographic stations from Fremantle west to $78{ }^{\circ} \mathrm{E}$, and then north to $4 \mathrm{O}$. Her track is shown in Figure 15.

U. S. NAVY

Survey vessels of the U. S. Navy have occupied hydrographic stations in the Persian Gulf and Andaman Sea, as shown in Figure 15.

The research vessels CHAIN of Woods Hole Oceanographic Institution, ARGO of Scripps Isntitution of Oceanography, and CONRAD of Lamont Geological Observatory are owned by the U. S. Nevy, and their operations are supported by the Office of Naval Research. The Office of Naval Research also supports part of the operations of the VEMA and HORIZON. The Navy is also providing one R5D aircraft for use in the Woods Hole Oceanographic Institution meteorological program and is supplying a NOMAD weather station. Support has been given to the National Oceanographic Data Center for research on data processing for the NOMAD buoy observations.

U. S. WEATHER BUREAU

Four planes of the Weather Bureau Research Flight, normally based in Miami, Florida, in hurricane observation, will operate in India from May to July 1963 and again in January and February 1964. The Weather Bureau is also assigning two professional meteorologists to the International Meteorological Center at Bombay. Radiosonde equipment is being loaned by the Weather Bureau for installation on the ANTON BRUUIN and ATLAMTIS II.

BUREAU OF COMMERCIAL FISHERIES

The research program of the Bureau of Commercial Fisheries in the Indian Ocean has the following objectives:

1. To study the distribution and abundance of adult tunas in relation to the circulation during the two monsoon seasons.

2. To study the relation of the apex predators (tunas, marlins, sharks, etc.) to the food-chain, standing crops and productivity. 



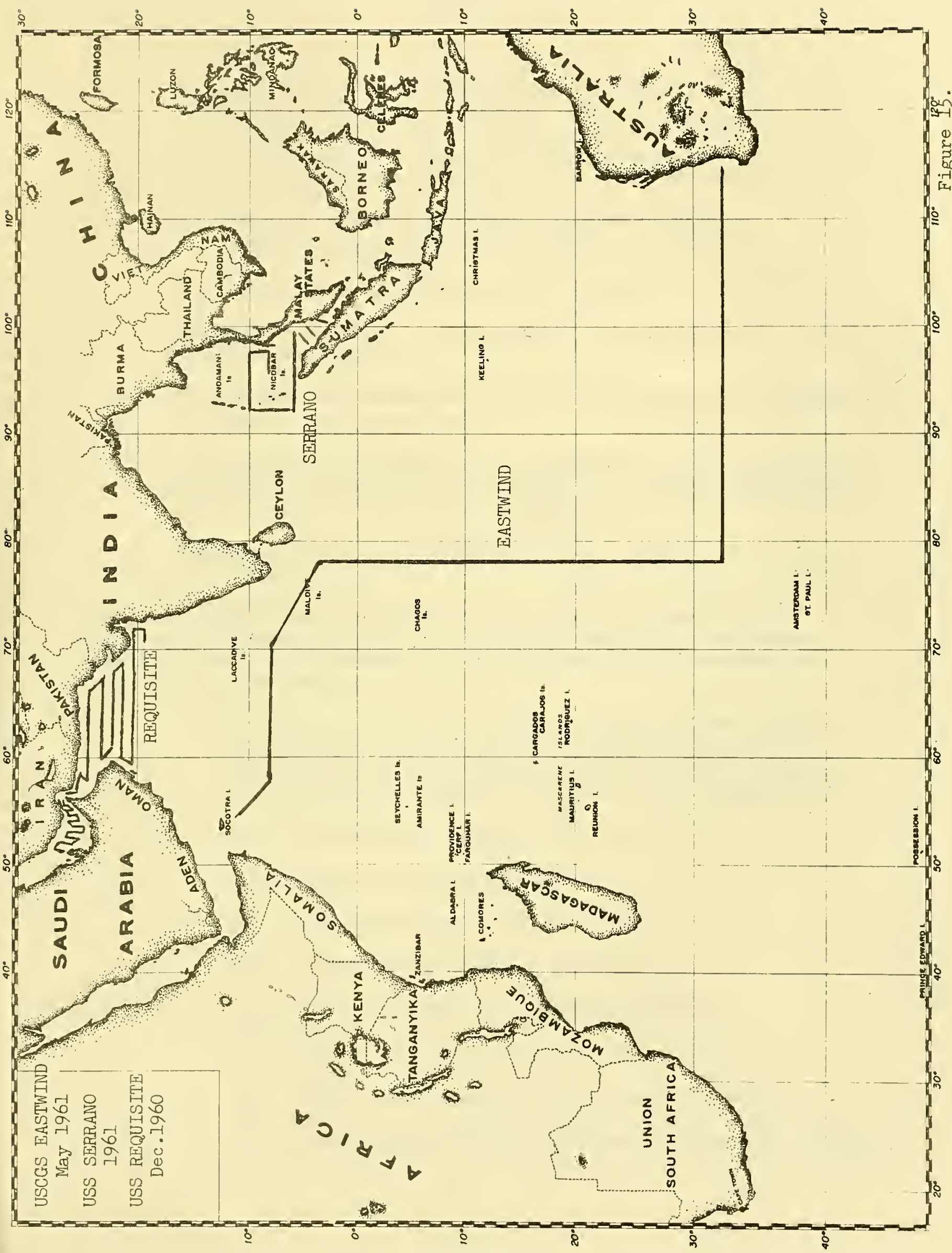



a. Organisms eaten (qualitative and quantitative analyses of stomach contents).

b. Standing crop of nekton (qualitative and quantitative analyses of mid-water trawl collections).

c. Standing crop of zooplankton (qualitative and quantitative analyses of zooplankton collections).

d. Phytoplankton productivity (cl4 uptake).

3. Investigate subpopulations (serology of apex predators: tunas, billfish, and sharks).

4. Distribution and abundance of larval and juvenile fish (plankton and night-light collections).

5. Zoogeography of zooplankton and zooplankton forms as blological indicators (distribution and abundance of selected zooplankters such as copepods of the genus Candacia).

6. Taxonomy, occurrence, and distribution of demersal fishes and invertebrates.

This program will be carrled out by personnel of the Bureau's Biological Laboratory, Honolulu, aboard the ANTON BRUUN. On cruises 2 and 5 , a party of 8 fishermen and 3 scientists will be embarked to engage in longline pishing as follows:

a. On each cruise, fish 60 baskets of gear at each station. Occupy 16 stations along each of two meridian; 13 of the stations to be at $5^{\circ}$ latitude intervals and remaining 3 stations to be occupied in areas of high abundance.

b. Data and biological samples to be collected.

(1) Catch (by species) and effort.

(2) Length and/or welght of each fish.

(3) Sex and general state of maturation.

(4) Preserve stomachs in 10 percent formalin.

(5) Preserve ovaries in 10 percent formalin.

(6) Preserve blood samples for serological studies.

(7) Preserve selected whole specimens for taxonomic studies. 

Bottom trawling to study the distribution and relative abundance of demersal species in relation to the topography and nature of the bottom, will be conducted on Cruises 1 and 4, using a single-warp shrimp trawl. Catches will be assessed quantitatively at sea, given a preliminary sorting, and sent to the U. S. National Museum for final distribution to qualified taxonomists for systematic studies of the fishes and invertebrates collected.

NATIONAL SC IENCE FOUNDATION

Support of the United States program for the IIOE by the National Science Foundation is epitomized by the following tabulation of grants made since 1960:

NSF Grant No. Institution Principal Title Amount

$G=11800$

G-16570

G16570Al

$G=17182$

National Academy of Sciences National Research Council

National Academy of Sciences National Research Council Investigator

R. C. Vetter

National Academy of Sciences National Research Council

Woods Hole Oceanographic Institution

University of Hawai1 Oceanographic Institution

$G-21960$

University of Rhode Island
G. D. Meid

L. Hoover

J. H. Ryther

C. S. Ramage

J. H. Ryther

Support to the $\$ 47,400$ Special Comittee on Oceanic Research of the International Council of Scientific Unions.

Support of Coordi- 56,900 nator, Indian Ocean Expedition

Support of Coordi- 44,200 nator, Indian Ocean Expedition

Planning of a pro- 24,000 gram in biology for the Indian Ocean Expedition

Support of U. S. 97,200 Meteorology Program of the Indian Ocean Expedition

U. S. Program in 450,000 biology for the International Indian Ocean Expedition

J. A. Knauss
Equatorial Circula-100,000 tion of the Indian ocean 


\begin{tabular}{|c|c|c|c|c|}
\hline NSF Grant & Institution & Principal & Title & Amouat \\
\hline Number & & Investigator & & \\
\hline G-22223 & $\begin{array}{l}\text { Office of } \\
\text { Naval Research }\end{array}$ & J. Hughes & $\begin{array}{l}\text { NOMAD weather } \\
\text { station for the } \\
\text { International } \\
\text { Indian Ocean } \\
\text { Expedition }\end{array}$ & $\$ 50,000$ \\
\hline G-22255 & $\begin{array}{l}\text { University of } \\
\text { California }\end{array}$ & R.L. Fisher & $\begin{array}{l}\text { Participation in } \\
\text { the International } \\
\text { Indian Ocean } \\
\text { Expedition }\end{array}$ & 150,000 \\
\hline$G-22260$ & Columbia Univ. & M. Ewing & $\begin{array}{l}\text { Participation in } \\
\text { the International } \\
\text { Indian Ocean } \\
\text { Expedition }\end{array}$ & 150,000 \\
\hline$G-22388$ & $\begin{array}{l}\text { University of } \\
\text { Mighigan }\end{array}$ & D.J. Portman & $\begin{array}{l}\text { Heat and water } \\
\text { vapor exchange for } \\
\text { the International } \\
\text { Indian Ocean } \\
\text { Expedition }\end{array}$ & 231,900 \\
\hline G-22389 & $\begin{array}{l}\text { Woods Hole } \\
\text { Oceanographic } \\
\text { Institution }\end{array}$ & A.F. Bunker & $\begin{array}{l}\text { Air-Sea Inter- } \\
\text { action for the } \\
\text { International } \\
\text { Indian Ocean } \\
\text { Expedition }\end{array}$ & 97,000 \\
\hline$G-22413$ & $\begin{array}{l}\text { University of } \\
\text { Hawaii }\end{array}$ & C.S. Ramage & $\begin{array}{l}\text { Atmospheric Cir- } \\
\text { culation Project } \\
\text { for the Interna- } \\
\text { tional Indian } \\
\text { Ocean Expedition }\end{array}$ & 146,600 \\
\hline G-23113 & $\begin{array}{l}\text { Woods Hole } \\
\text { Oceanographic } \\
\text { Institution }\end{array}$ & A.F. Bunker & $\begin{array}{l}\text { Research Aircraft } \\
\text { for meteorological } \\
\text { program of the } \\
\text { International Indian } \\
\text { Ocean Expedition }\end{array}$ & 100,000 \\
\hline
\end{tabular}


U. S. COAST AND GEODETIC SURVEY

The USC\&GS Ship PIONEER will sall in mid-February of 1964 from San Francisco to take part in the International Indian Ocean Expedition, returning to San Francisco the following September. In addition to underway observations, en route to and from the Indian Ocean, the PIONEER wLIl concentrate on gravity, magnetic, and hydrographic operations in the Andaman Sea and the eastern Bay of Bengal. Space will be made avallable aboard the vessel for two meteorologists and one or two biologists. Three north-south profiles of oceanographic stations are planned from $5^{\circ} \mathrm{N}$ to $5 \mathrm{~S}$ across the Equator south of the Bay of Bengal.

These are only tentative plans covering work on specific Coast and Geodetic Survey projects. It is anticipated that they will be modified and added to as the information prom other participants becomes available and as other organizations develop cooperative programs with the PIONEER.

These plans are predicated on the assumption that TRANSIT navigation will be available for determing ship positions throughout the expedition.

Leg I - San Francisco to Singapore

Leg II - Singapore Trincomalee (Figure 16)

From Singapore, the track will be northwest through the Malacca Straits into the Andaman Sea. The actual tracklines in the Andaman Sea will depend in part on the results of the work of the ARGO which returns from this area in the early summer of 1963. In general, how ever, there will be a series of sawtooth crossings of the Andaman Sea carrying out all of the standard underway observations with special attention paid to the bathymetry and the gravity work. Sediment cores and bottom photographs will be taken in the Andaman Sea along these lines. Rock dredgings will be attempted at places where the topography suggests that rock outcrops might be present. Planned tracklines in this area will be modified in the field as dictated by the bottom topography and gravity anomalies encountered. The pattern will include at least two crossings of the Andaman Nicobar Ridge into depths of at least 3000 meters west of the ridge. These could conceivably be through Ten Degree Channel and Duncan Pass. At the nortbern end of the Andaman Sea, special lines shall be run to determine if submarine channelling extends seaward of the mouths of the Irrawaddi River.

From the Andaman Sea, the ship will pass into the Bay of Bengal where the underway operations, cores (or dredgings), and bottom photography will continue along a series of East-West lines at approximately two-degree spacing from the coast of Burma out to approximately $88^{\circ} \mathrm{E}$. Topographic, gravimetric, or magnetic anomalies found along these lines will be developed more fully. Special 


care will be taken along the more northerly of these lines to look for any southerly extension of the Ganges Canyon. This has been surveyed in some detail by the Pakistan Navy as far as the edge of the continen tal shelf. The GALATHEA's lines showed that it extends south into the Bay of Bengal beyond the shelf, but its extent is not known. It is possible that the valley found by the ALBATROSS east of Ceylon may be the extension of this Ganges Canyon. After a stop at Calcutta, the PIONEER will carry out a detailed survey of the Ganges Submarine Canyon seaward of the continental shelf. The canyon will be traced as far seaward as is possible. Cores will be obtalned from the canyon floor where possible and attempts will be made to dredge the canyon walls. Bottom photographs will be obtained where camera lowerings appear feasible. If the canyon terminates well north of the latitude of Ceylon, the east-west lines previously run in the eastern Bay of Bengal shall be continued westward from $88^{\circ}$ to the coast of India. If the canyon continues south to or beyond Ceylon, it shall be followed to its termination with cross sections run at frequent intervals.

On the termination of this project, the ship will proceed to Trincomalee, Ceylon.

Leg III - Trincomalee to Djakarta

HO Charts 2523 and 3689 show hard ridges through which has been cut a submarine canyon that heads in Trincomalee and Goddiyar Bays on the northeast coast of Ceylon. The canyon has apparently been cut in quartzite and other hard Pre Cambrian rocks. The canyon extends seaward to depths of at least 800 fathoms where the soundings terminate. As the ship leaves Trincomalee, this canyon will be traced seaward with a set of profiles, and an attempt will be made to dredge the steep walls. Sediment cores and bottom photographs will be obtalned where possible.

Upon the completion of the canyon survey, three north-south sections of oceanographic stations wili be ocuupied from $5^{\circ} \mathrm{N}$ to $5^{\circ} \mathrm{S}$ along $84^{\circ} \mathrm{E}, 88^{\circ} \mathrm{E}$, and $92^{\circ} \mathrm{E}$. Stations w111 be at $5^{\circ}, 4^{\circ}$, and $3^{\circ}$, and at $\frac{1}{2}$ degree intervals to the Equator for a total of 17 stations along each profile. The stations at $5^{\circ}, 3^{\circ}$ and $1^{\circ} \mathrm{N}$ and $\mathrm{S}$ will be deep stastions to the bottom, the others will be to 2000 meters. Standard bottle spacing will be used, except that depth of stations and bottle spacing may be modified in the light of other results obtained before the PIONEER sails.

From the southern end of the easternmost line $\left(5^{\circ} \mathrm{S}, 92^{\circ} \mathrm{E}\right)$, the track to $\mathrm{Djakarta}$ is tentatively planned to accomplish two crossings of the northwestward extension of the trend of the Java Treach. These would be underway observations as described above. The first line would approach the Sumatra coast near Padang and thex turn southwest continuing to the latitude of the sunda strait, thence due east through the Sunda Strait to Djakarta. The tracklines between the 

end of the oceanographic stations and Djakarta are only tentative and will be changed to supplement the work of the ARGO currently operating in this area. 
